\title{
Sentiment Analysis Towards Courier Service: Case Study on JNE Semarang
}

\author{
Erika Devi Udayanti ${ }^{1}$, Aulia Arif Rahman ${ }^{2}$, Etika Kartikadharma ${ }^{3}$ \\ \{ erikadevi@dsn.gmail.com¹, 112201304994@mhs.dinus.ac.id ${ }^{2}$, \\ etika.kartikadarma@dsn.dinus.ac.id ${ }^{3}$ \} \\ Universitas Dian Nuswantoro, Jl. Imam Bonjol No.207, Pendrikan Kidul, Semarang Tengah, Kota \\ Semarang, Jawa Tengah $50131^{123}$
}

\begin{abstract}
Society as customers often gives an opinion about the company's product and service. Opinion delivered by customers can be both in positive and negative judgments. It is in the form of opinions that describe a customer's emotional expression. Therefore, it is important for companies to be able to understand customers' emotional tendencies from the opinions of texts submitted online. In this study, data text is used in the form of opinions of users of JNE Semarang courier services to conduct sentiment analysis by mining opinions from customer reviews. This research generally proposes the implementation of sentiment analysis of JNE customer's opinion by using K-nearest Neighbor algorithm to classify customer's opinion regarding JNE services. The Confusion Matrix model is adapted to measure the accuracy of the classification results. And the results show that majority opinions classify into negative sentiment with the highest accuracy on value $\mathrm{k}=7$.
\end{abstract}

Keywords: sentiment analysis, jne, classification, k-nn.

\section{Introduction}

Courier service business is recently having a very good progress. This kind of business has profitable opportunity since the demand from society is also increasing in delivery service. The growth of e-commerce in delivering goods from online business also becomes the trigger in the increasing of courier service. However, society needs to be selective in choosing services offered by such companies on which service is better and more suitable to fulfil the need of expedition. Society as the customers often gives an opinion about the company's product and service. Opinion delivered by customers can be both in positive and negative judgments. It is in the form of opinions that describe a customer's emotional expression. The development of the internet has brought social change to society in many ways, one of which is in expressing opinions. Social media is chosen by many people to convey their perceptions or opinions. One of the popular social media is Twitter which is a microblogging service where users can post "tweets" of 140 characters [1]. Indonesia is the 5th country with the most twitter accounts in the world where twitter users in Indonesia reach $77 \%$ who are active every day. There are at least 4.1 million tweets originating from Indonesia. There are $77 \%$ of twitter users in Indonesia active every day and 54\% of them make 2 tweets a day. From these enormous number of data contains potential information which is useful for an organization or a company if the company explore the information deeper. Therefore, it is important for

ICCSET 2018, October 25-26, Kudus, Indonesia

Copyright () 2018 EAI

DOI 10.4108/eai.24-10-2018.2280499 
companies to be able to understand customers' emotional tendencies from the opinions of texts submitted online. Companies can explore this knowledge through sentiment analysis or often called opinion mining [2].

In this study, twitter data is used in the form of users opinions of JNE Semarang courier services to conduct sentiment analysis by mining opinions from customer reviews. This study generally proposes the implementation of sentiment analysis of JNE customer's opinion by using K-nearest Neighbor algorithm to classify customer's opinion regarding JNE services. The result of this research is expected to reveal customer's opinion or problem towards JNE's services. The knowledge gained can then be used by the company in an effort to develop customer relationship management to be able to better control the market and provide services according to market demand (customers).

\section{Related Work}

The activity of opinion mining is computation study to detect and express opinion, sentiment, evaluation, behaviour, emotion, subjectivity, assessment, or view in a current text [3]. Sentiment analysis is the process of exploring the opinions of a text on a particular object [4] [5]. This exploration is carried out to see a person's opinion tendency will have a positive or negative opinion tendency. A number of studies have been conducted related to sentiment analysis. Some algorithms that are often used include Naïve Bayes, K-Nearest Neighborhood, and SVM [6],[7],[8],[9] .

Sentiment analysis regarding services on online motorcycle taxi services is done to classify public opinion that is positive, negative or neutral [6]. Naive Bayes algorithm is adapted to classify the negative or positive opinion of the community with an accuracy rate of $80 \%$. The study related to the recommendation of the final lecturer was carried out in research [7]. The final project proposal data becomes a data source in the text mining process that utilizes the KNN algorithm as a classification algorithm. Classification results obtained with an accuracy value of $60 \%$.

In a study related to android game user sentiment analysis [8], the KNN algorithm was applied to classify user reviews into two forms namely positive and negative. Data is taken from product reviews on various e-commerce sites. From the evaluation results, the accuracy of the algorithm reached $74.5 \%$. Another study is sentiment analysis regarding public transportation services in the city. This research is to classify positive or negative opinions from the community through twitter to find out the assessment of public transportation services that are in the city. The dataset uses Indonesian-language opinions, choosing as a sample of public transportation such as angkot, kopaja, metromini and transjakarta [9].

\section{Methodology}

The process of sentiment analysis in this study refers to [5]. Figure 1 as a research methodology framework, where this study begins with data collecting through the tweet data crawling process to obtain document data. It is followed by preprocessing text to prepare the data set to be processed. Next is a feature analysis by weighting each term followed by 
classification using the $\mathrm{KNN}$ algorithm. And at the last step is to do an evaluation using the confusion matrix model.

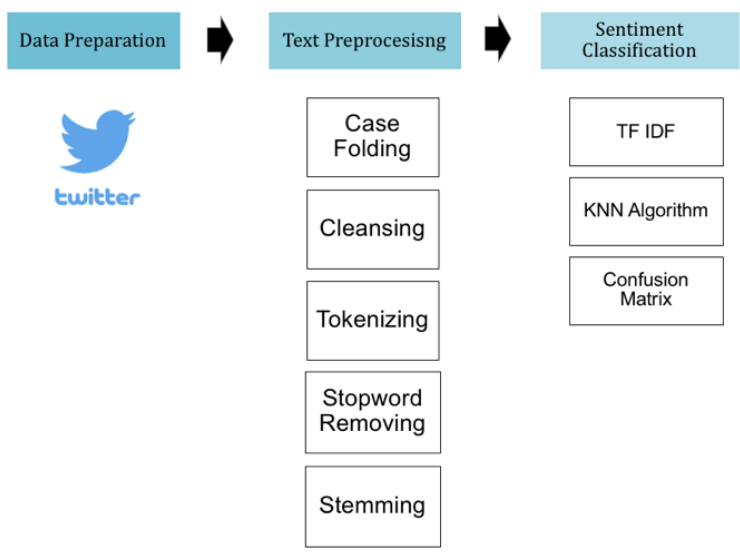

Fig. 1. Research Methodology.

\subsection{Data Collecting}

The dataset domain that will be used in this research is the service review of jne Semarang. The data domain that will be used in this research is the jne service review dataset. Data collecting done in this research is taken from Twitter by accessing Twitter Library or Twitter API to do raw crawling data. This method of data collecting uses programing language $R$ supported by Rstudio. From the data crawling results, 1000 random tweets were obtained from twitter that containing "@jne" or "\#jne" and using Indonesian language. The data divided into training data and testing data.

\subsection{Text Preprocessing}

The initial step in text mining is text preprocessing. This process aims to obtain the data set that will be used in the classification process later. Activities that need to be done in text preprocessing are include case folding, cleansing, tokenizing, stopwords removing, and stemming.

a. Case folding, this step aims to alter all letters into lowercase form in the current document. And also non-letter characters such as emoticons.

b. Cleansing, it is the process of omitting characters such as HTML, keyword, emoticon, hashtag, username, url, and email.

c. Tokenizing, this stage is carried out to separate or break a sentence into separate words.

d. Stopwords removing is conducted to omit words that do not contain meaning or do not describe something in Indonesian like preposition such as "dan" (and), "ke" (to), "ini" (here/this), "yang" (which), etc. 
e. Stemming is done to eliminate words that still contain an affix so that they become the basic words. For example, the word "menulis", "ditulis", "menuliskan", and "dituliskan" are altered into their root "tulis" (write). This research adopts sastr awi library in the process of stemming.

After conducting the processes above, it can be compared between raw data and clean data after text preprocessing. In the figure 2 below shows the comparison between raw data (tweet awal) and data set (tweet hasil).

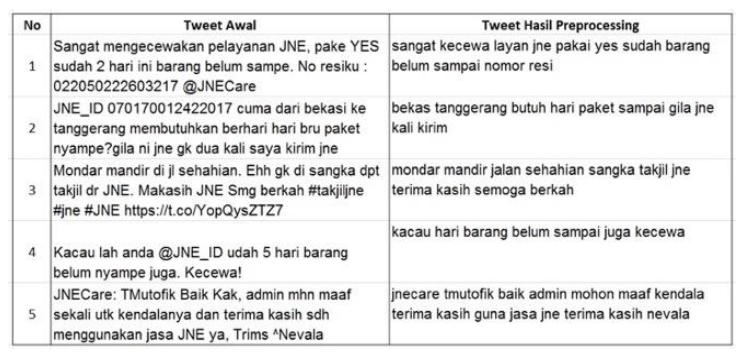

Fig. 2. Text Preprocessing Result.

\subsection{Feature Analysis}

Before the classification is carried out, the weighting term must be done first, by calculating the frequency for all the words (terms) contained in each document [10]. Terms are counted using Term Frequency - Inverse Document Frequency (TF-IDF) method [7] [10][11]. This methode is often used in text mining and information retieval. The following function is to calculate the IDF TF value.

$$
T F\left(d_{j}, t_{k}\right)=f\left(d_{j}, t_{k}\right)
$$

where $\boldsymbol{f}\left(\boldsymbol{d}_{\boldsymbol{j}}, \boldsymbol{t}_{\boldsymbol{k}}\right)$ is the appearance of the word $t$ in the document $d$

$$
\operatorname{IDF}(t)=\log \frac{N}{d f(t)}
$$

where $\mathrm{df}(\mathrm{t})$ is number of documents that have the word $t$

$$
T F I D F=T F\left(d_{j}, t_{k}\right) . I D F\left(t_{k}\right)
$$

Term Frequency (TF) is the frequency to count how often terms appear in a current document which is previously proceeded or counted. The Inverse Document Frequency (IDF) process is conducted by counting the value of the current term on how often it appears in some documents. The more often a term appears, the less IDF value is gained. 


\subsection{Evaluation}

The Confusion Matrix model is adapted to measure the accuracy of the classification results. The measurements in the form of matrix tables by calculating statistical measures, namely True Positives (TP), True Negatives (TN), False Positive (FP) and False Negatives (FN) [12].

Table 1. Confusion Matrix

\begin{tabular}{ccc}
\hline Actual & \multicolumn{2}{c}{ Predicted Class } \\
Class & + & - \\
\hline+ & True & False \\
& Positives & Negatives \\
- & False & True \\
& Positives & Negatives \\
\hline
\end{tabular}

The confusion matrix model equation is obtained by calculating the following models:

$$
\begin{array}{ll}
\text { Precission } & =\frac{T P}{T P+F P} \\
\text { Recall } & =\frac{T P}{T P+F N} \\
\text { Precision } & =\frac{T P}{T P+F P} \\
\text { Accuracy } & =\frac{\sum T P+\sum T N}{\sum \text { Data Uji }}
\end{array}
$$

$T P=$ Number of True Positives

$T N=$ Number of True Negatives

$P \quad=$ Number of Record Positives

$N=$ Number of Tupel Negatives

$F P=$ Number of False Positives

\section{Result}

In the classification process, the training data used is 700 tweets and 300 testing data. From the results of the k-NN model processing, the classification for positive sentiments according to the prediction of 132 data was obtained, then 35 data were predicted to be positive but included in the category of negative sentiment. As for the negative sentiment data, which corresponds to the prediction that the data is negative is 116 , and for the negative review prediction included in the positive review prediction is 17 .

The evaluation is done by giving some $k$ values randomly, starting from $3,5,7,9,11$ and 13. From the results of the classification on each experiment, then the evaluation is done using 
a confusion matrix, where the process measures the value of Accuracy, Precision, Recall, and F-Measure.

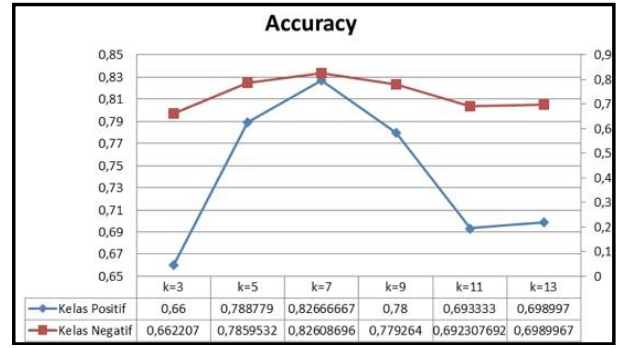

Fig. 3 (a) Accuracy Result

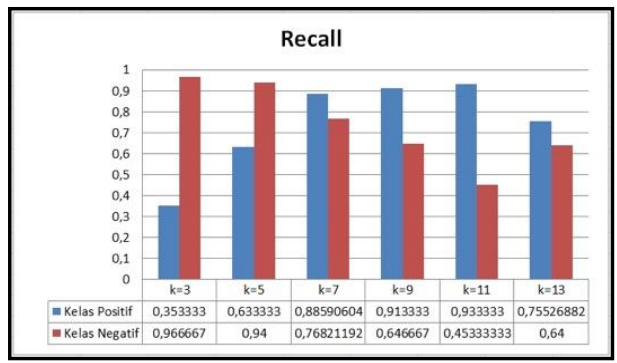

Fig. 3 (c) Recall Result

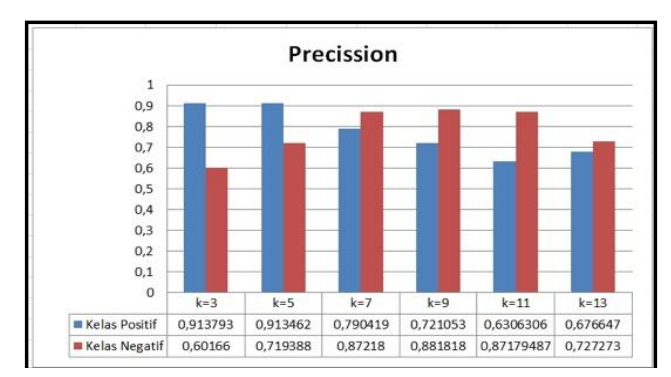

Fig. 3 (b) Precision Result

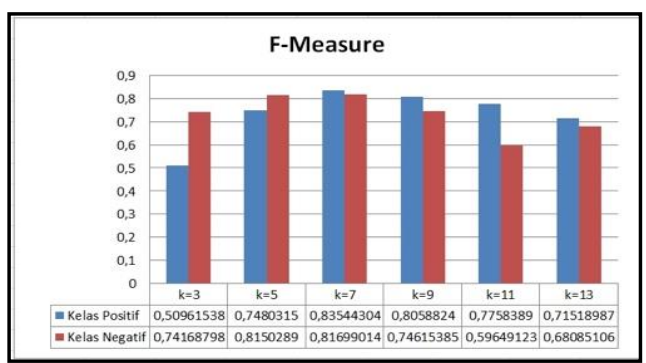

Fig. 3 (d) F-measure Result

After classification on each value $\mathrm{k}$ is finished, the following process is calculated using the confusion matrix, which determines the value of Accuracy, Precision, Recall, and FMeasure. Figure 3(a) shows the level of accuracy of the results of classification testing. The results of the evaluation showed that the highest accuracy results were obtained at the value of $\mathrm{k}=7$ with the accuracy value of $82.7 \%$. The following is a confusion matrix model table from a classification with a value of $\mathrm{k}=7$.

Based on classification result using KNN algorithm, it can be concluded in the graph so the comparison among value $\mathrm{k}$ can be seen by Confusion Matrix calculation into positive and negative class.

Table 2. Confusion Matrix

\begin{tabular}{lccc}
\hline & True Positive & True Negative & Class Precision \\
\hline Prediction & 132 & 17 & $79,04 \%$ \\
$\begin{array}{l}\text { Positive } \\
\text { Prediction }\end{array}$ & 35 & 116 & $87,22 \%$ \\
$\begin{array}{l}\text { Negative } \\
\text { Class }\end{array}$ & & $76,82 \%$ & \\
Recall & $88,59 \%$ & & \\
\hline
\end{tabular}




\section{Conclusion}

As one of courier service companies, JNE can explore knowledge towards society's view and assessment by collecting public opinions. The knowledge gain by JNE results from alternatives ways to decide company business strategies taken from various opinions from JNE's customers. This research on sentiment analysis classifies 2 kinds of sentiments, both positive and negative ones. The classification is conducted using K-Nearest Neighbor. This results that majority opinions classify into negative sentiment. Evaluation data gained from 700 training data and 300 testing data show the highest Accuracy on value $k=7$ or $82,66 \%$ for positive sentiments and $82,60 \%$ for negative sentiments. 300 terms (words) has often emerged on customers' opinion through the process of building words cloud.

\section{References}

[1] B. Saberi and S. Saad, "Sentiment Analysis or Opinion Mining: A Review,” Int. J. Adv. Sci. Eng. Inf. Technol., vol. 7, 2017.

[2] D. Dwiki and A. Nur, "Pengembangan Aplikasi Sentiment Analysis Menggunakan Metode Naive Bayes ( Studi Kasus Sentiment Analysis dari media Twitter )," no. November, pp. 2-3, 2015.

[3] M. Ramdhani Ali and O. Rahim Handoko, "Analisis Sentimen Untuk Mengukur Popularitas Tokoh Publik Berdasar Data Pada Media Sosial Twitter Menggunakan Algoritma Data Mining Dengan Teknik Klasifikasi,” J. Inf., vol. VI, no. 2, p. 56, 2014.

[4] K. Zvarevashe and O. Olugbara O, "A Framework for Sentiment Analysis with Opinion Mining of Hotel Reviews," in Conference on Information Communications Technology and Society (ICTAS), 2018.

[5] H. Kaur, V. Mangat, and Nidhi, "A Survey of Sentiment Analysis techniques," in International conference on I-SMAC (IoT in Social, Mobile, Analytics and Cloud), 2017, p. 921.

[6] D. G. Nugroho, Y. H. Chrisnanto, and A. Wahana, "Analisis Sentimen pada Jasa Ojek Online Menggunakan Metode Naive Bayes," pp. 156-161, 2015.

[7] Z. Efendi, "Text Mining Classification Sebagai Rekomendasi Dosen Pembimbing Tugas Akhir Program Studi Sistem Informasi," in Seminar Nasional Teknologi Informasi, Komunikasi dan Industri (SNTIKI), 2017, pp. 18-19.

[8] S. Sahara, "Penerapan Metode K-Nearest Neighbors Untuk Analysis Sentiment Review Game Pada Android,” J. Evolusi, vol. 4, 2016.

[9] A. Novantirani, "Analisis Sentimen pada Twitter Mengenai Penggunaan Transportasi Umum Darat Dalam Kota dengan Metode Support Vector Machine,” Telkom University, 2015.

[10] X. Zhang and X. Zheng, "Comparison of Text Sentiment Analysis based on Machine Learning," in 15th International Symposium on Parallel and Distributed Computing, 2016.

[11] A. Sukma, B. Zaman, and E. Purwanti, "Klasifikafi Dokumen Temu Kembali Informasi dengan K-Nearest Neghbour,” Rec. Libr. J., vol. 1, no. 2, 2015.

[12] M. J R Navin and P. R, "Performance Analysis of Text Classification Algorithms using Confusion Matrix,” Int. J. Eng. Tech. Res., vol. 6, no. 4, 2016. 